\title{
Probiotic in lamb rennet paste enhances rennet lipolytic activity, and conjugated linoleic acid and linoleic acid content in Pecorino cheese
}

\author{
A. Santillo, ${ }^{*}$ M. Albenzio, ${ }^{* 1}$ M. Quinto, $†$ M. Caroprese, ${ }^{*}$ R. Marino, ${ }^{*}$ and A. Sevi* \\ *Department of Production and Innovation in Mediterranean Agriculture and Food Systems (PrIME), and \\ †Department of Agro-Environmental Science, Chemistry and Plant Protection (Di.S.A.C.D.), University of Foggia, 71100 Foggia, Italy
}

\begin{abstract}
Cheeses manufactured using traditional lamb rennet paste, lamb rennet paste containing Lactobacillus acidophilus, and lamb rennet paste containing a mix of Bifidobacterium lactis and Bifidobacterium longum were characterized for the lipolytic pattern during ripening. Lipase activity of lamb rennet paste, lamb rennet containing $L b$. acidophilus, and lamb rennet containing a mix of bifidobacteria was measured in sheep milk cream substrate. Rennet paste containing probiotics showed a lipase activity 2 -fold greater than that displayed by traditional rennet. Total free fatty acid (FFA) in sheep milk cream was lower in lamb rennet paste $(981 \mu \mathrm{g} / \mathrm{g}$ of milk cream) than in lamb rennet containing $L b$. acidophilus $(1,382.4 \mu \mathrm{g} / \mathrm{g}$ of milk cream) and in lamb rennet containing a mix of bifidobacteria $(1,227.5 \mu \mathrm{g} / \mathrm{g}$ of milk cream) according to lipase activity of lamb rennet paste. The major increase of FFA in all cheeses occurred during the first $30 \mathrm{~d}$ of ripening with the greatest values being observed for C16:0, C18:0 C18:1. At $60 \mathrm{~d}$ of ripening all cheeses showed a reduction in the amount of free fatty acids; in particular, total free fatty acids underwent a decrease of more than $30 \%$ from 30 to $60 \mathrm{~d}$ in cheeses manufactured using traditional lamb rennet paste, whereas the same parameter decreased $10 \%$ in cheeses manufactured using lamb rennet paste containing $L b$. acidophilus and cheeses manufactured using lamb rennet paste containing a mix of B. lactis and B. longum. Cheese containing Lb. acidophilus was characterized by the greatest levels of total conjugated linoleic acids (CLA) 9-cis, 11-trans CLA and 9-trans, 11-trans CLA, whereas cheese containing bifidobacteria displayed the greatest levels of free linoleic acid. Rennet pastes containing viable cells of $L b$. acidophilus and a mix of B. lactis and B. longum were able to influence the amount of FFA and CLA in Pecorino cheese during ripening.
\end{abstract}

Received July 31, 2008.

Accepted November 19, 2008.

${ }^{1}$ Corresponding author: m.albenzio@unifg.it
Key words: conjugated linoleic acid, rennet paste, probiotic, Pecorino cheese

\section{INTRODUCTION}

Lipolysis is an important biochemical event occurring during cheese ripening that leads to the formation of FFA, which are precursors of compounds that are volatile and contribute to flavor (Collins et al., 2003). However, excessive lipolysis could result in the presence of off-flavors, because high concentrations of volatile FFA influence cheese flavor either directly or as precursors for other compounds (Pinho et al., 2003).

Lipases in cheese originate from different sources such as milk, rennet paste, starter, adjunct starter, nonstarter bacteria, and the addition of exogenous lipases (Deeth and Fitz-Gerald, 1995; Fox and Wallace, 1997; McSweeney and Sousa, 2000). Rennet paste is used for ovine and caprine cheese production in Mediterranean countries and its lipolytic activity is responsible for the extensive lipolysis occurring during ripening. Rennet paste contains lipases with different specific characteristics and activities identified as pregastric esterase, highly specific for realizing free fatty acids from the sn-1 and sn-3 positions of tryacylglycerols, and gastric lipase (Richardson et al., 1971; Nelson et al., 1977).

Sheep milk is commonly used for cheese production due to its high fat and total solids content. However, the high fat content in sheep milk might limit the demand for milk products by health-conscious consumers (Zhang et al., 2006). Several studies have shown the possibility of manipulating milk fat acid composition through animal diet to increase the concentration of polyunsaturated fatty acids, health-promoting conjugated linoleic acids (CLA), and linoleic acid (Cabiddu et al., 2006; Van Nieuwenhove et al., 2007). An alternative strategy to improve the nutritional value of dairy products is the incorporation of probiotic CLA-forming cultures into cheese to increase CLA concentration in the human diet (Van Nieuwenhove et al., 2007). In a previous study, Santillo et al. (2007) showed an increase in CLA levels in cheese produced using lamb rennet paste obtained from lambs fed milk substitute contain- 
ing Lactobacillus acidophilus. Many experiments have been conducted to assess the ability of Bifidobacterium species to produce CLA (Coakley et al., 2003; Oh et al., 2003); however, little is known about the possibility to ameliorate the lipolytic profile of cheese by using probiotic cultures.

This study was undertaken to evaluate the lipolytic pattern, in terms of FFA and CLA, in Pecorino cheese produced using lamb rennet paste containing viable cells of $L b$. acidophilus and a mix of Bifidobacterium longum and Bifidobacterium lactis during ripening.

\section{MATERIALS AND METHODS}

\section{Incorporation of Probiotic Cultures in Lamb Rennet Paste}

The abomasa for rennet paste production were extracted from suckling lambs reared in the Apulia region of southern Italy. The production of rennet paste and the incorporation of lyophilized probiotic cultures were done according to the protocol described in Santillo and Albenzio (2008). Briefly, the perivisceral fat was removed from abomasa and the whole stomach was cut into slices, salt was added (18-20\% wt/wt), and the samples were ripened at $6^{\circ} \mathrm{C}$ and $70 \%$ relative humidity for 2 mo. Lyophilized cultures of Lb. acidophilus (LA-5) and B. lactis (BB-12) and B. longum (BB-46; Chr. Hansen, Milan, Italy) were inoculated in rennet paste at a concentration of $11 \log _{10}$ cfu per $g$ of rennet paste.

\section{Analyses of Rennet Paste}

Lipolytic Activity in the Rennet Paste. The lipolytic activity of each rennet paste on sheep milk cream substrate was determined according to the method described by Addis et al. (2005). Briefly, the milk cream was obtained by centrifugation of fresh sheep milk, and then mixed with reconstituted skimmed milk to obtain the final concentration of $25 \%$ (wt/wt). Rennet extract $(2.5 \mathrm{~mL} ; 20 \% \mathrm{wt} / \mathrm{vol})$ was added to $25 \mathrm{~g}$ of sheep milk cream substrate and incubated at $37^{\circ} \mathrm{C}$ for $24 \mathrm{~h}$. The lipolytic activity of each rennet was determined by titration of FFA in the total volume of the incubate with $0.1 \mathrm{M} \mathrm{NaOH}$ until a $\mathrm{pH}$ of 8.5 was reached. The rennet extract $(2.5 \mathrm{~mL})$ and the blank $(25$ $\mathrm{g}$ of the same substrate without rennet extract) were also titrated in the same way. The lipolytic activity of each assay was calculated by subtracting the $\mathrm{NaOH}$ added to the blank and to the rennet extract from the $\mathrm{NaOH}$ volume added to the incubate. Free fatty acid and CLA composition of sheep milk cream samples (blank) are presented in Table 1.
Table 1. Free fatty acids and conjugated linoleic acids ${ }^{1}$ (CLA; $\mu$ mol per $\mathrm{g}$ of milk cream) profile of sheep milk cream substrate

\begin{tabular}{lc}
\hline Item & Sheep milk cream \\
\hline C4:0 0 & 0.477 \\
C6:0 $8: 0$ & 0.188 \\
C10:0 & 0.121 \\
C12:0 & 0.840 \\
C14:0 $16: 0$ & 0.216 \\
C18:0 & 1.041 \\
C18:1 $18: 2$ & 0.237 \\
Total FFA & 0.955 \\
9-trans, 11-trans CLA & 0.064 \\
10-trans,12-cis CLA & 0.038 \\
9-cis, 11-trans CLA & 4.177 \\
\hline
\end{tabular}

${ }^{1} \mathrm{CLA}$ content was expressed as the sum of free and bound isomers.

A lipolytic unit (LU) was defined as the amount of enzyme that produces, on the sheep milk cream substrate, after $24 \mathrm{~h}$ at $37^{\circ} \mathrm{C}$, an amount of FFA titratable with $1 \mu \mathrm{Eq}$ of $\mathrm{NaOH}$, until a $\mathrm{pH}$ of 8.5 was reached. The values are given as lipolytic units per gram of rennet paste. The determination of FFA and of CLA on sheep milk cream substrate was conducted following the same protocol described for cheese.

\section{Analyses of Ovine Cheese}

Ovine Cheese Production. The same amount (40 $\mathrm{g}$ of rennet per $100 \mathrm{~L}$ of milk) of experimental rennet paste was used for cheesemaking. Three Pecorino cheese-making trials were performed in triplicate at industrial plant scale according to the protocol reported by Santillo and Albenzio (2008) and analyzed at 1 , $7,15,30$, and $60 \mathrm{~d}$ of ripening. Cheeses were denoted as cheese manufactured using traditional lamb rennet paste (RP-CH), cheese manufactured using lamb rennet paste containing $L b$. acidophilus (RPL-CH), cheese manufactured using lamb rennet paste containing $B$. lactis and B. longum (RPB-CH).

Determination of FFA in Cheese. Volatile FFA in cheese were extracted with diethyl ether: hexane (1:1, $\mathrm{vol} / \mathrm{vol}$ ), after grinding with sodium sulfate and addition of 2.5 $M$ sulfuric acid (Ha and Lindsay, 1990). Free fatty acids were isolated using an aminopropyl column as adsorbent; the desorption of the FFA was carried out with $2 \%$ formic acid in diethyl ether (de Jong and Badings, 1990). The underivatized FFA were separated directly by capillary gas chromatography (Varian 3800, Varian, Milan, Italy) using a capillary column (CP 8853, WCOT fused silica $60 \mathrm{~m}, 0.32 \mathrm{~mm}, 0.25 \mu \mathrm{m}$, Varian). Operating conditions were a helium flow rate of 1.3 $\mathrm{mL} / \mathrm{min}$, a flame-ionization detector at $250^{\circ} \mathrm{C}$, a split/ 
Table 2. Free fatty acids and conjugated linoleic acids ${ }^{1}$ (CLA; $\mu$ mol per $g$ of milk cream) profiles of sheep milk cream substrate incubated with different rennet pastes $^{2}$

\begin{tabular}{lccccc}
\hline Item & $\mathrm{RP}$ & $\mathrm{RPL}$ & $\mathrm{RPB}$ & $\mathrm{SEM}$ & Effect \\
\hline C4:0 & $0.513^{\mathrm{a}}$ & $1.036^{\mathrm{b}}$ & $1.061^{\mathrm{b}}$ & 0.03 & $* *$ \\
C6:0 $8: 0$ & $0.255^{\mathrm{a}}$ & $0.258^{\mathrm{a}}$ & $0.424^{\mathrm{b}}$ & 0.02 & $*$ \\
C10:0 & $0.125^{\mathrm{a}}$ & $0.195^{\mathrm{b}}$ & $0.314^{\mathrm{c}}$ & 0.01 & $* * *$ \\
C12:0 & $0.894^{\mathrm{a}}$ & $1.165^{\mathrm{b}}$ & $0.917^{\mathrm{a}}$ & 0.02 & $*$ \\
C14:0 & $0.257^{\mathrm{a}}$ & $0.355^{\mathrm{b}}$ & $0.274^{\mathrm{a}}$ & 0.01 & $* *$ \\
C16:0 & $1.090^{\mathrm{a}}$ & $1.398^{\mathrm{b}}$ & $1.312^{\mathrm{b}}$ & 0.01 & $* * *$ \\
C18:0 & $0.331^{\mathrm{a}}$ & $0.462^{\mathrm{b}}$ & $0.474^{\mathrm{b}}$ & 0.02 & $*$ \\
C18: $18: 2$ & $1.131^{\mathrm{b}}$ & $1.558^{\mathrm{c}}$ & $1.036^{\mathrm{a}}$ & 0.01 & $* * *$ \\
9-trans, 11-trans CLA & $0.066^{\mathrm{a}}$ & $0.241^{\mathrm{b}}$ & $0.192^{\mathrm{b}}$ & 0.02 & $*$ \\
10-trans, 12 -cis CLA & $0.033^{\mathrm{a}}$ & $0.047^{\mathrm{a}}$ & $0.206^{\mathrm{b}}$ & 0.01 & $* *$ \\
9-cis, 11-trans CLA & $0.060^{\mathrm{a}}$ & $0.075^{\mathrm{b}}$ & $0.065^{\mathrm{a}}$ & 0.01 & $*$ \\
\hline
\end{tabular}

${ }^{\mathrm{a}-\mathrm{c}}$ Means in rows with different superscripts differ for each item $(P<0.05)$.

${ }^{1} \mathrm{CLA}$ content was expressed as the sum of free and bound isomers.

${ }^{2} \mathrm{RP}=$ traditional lamb rennet paste; $\mathrm{RPL}=$ lamb rennet paste containing Lactobacillus acidophilus; $\mathrm{RPB}=$ lamb rennet paste containing Bifidobacterium lactis and Bifidobacterium longum.

${ }^{*} P<0.05 ;{ }^{* *} P<0.01 ;{ }^{* * *} P<0.001$.

splitless injector at $250^{\circ} \mathrm{C}$ with a split ratio $1: 10$ and an injection volume of $1 \mu \mathrm{L}$. The temperature program of the column was 5 min at $65^{\circ} \mathrm{C}$, increased at rate of $4^{\circ} \mathrm{C} /$ min to a final temperature of $220^{\circ} \mathrm{C}$, and then held for $20 \mathrm{~min}$. The individual fatty acids peaks were identified by comparison of retention times with those of known mixture of standard fatty acids (Sigma-Aldrich Chemie, Steinheim, Germany).

Determination of $C L A$ in Cheese. Pure CLA isomers were purchased as fatty acid methyl esters from Matreya Inc. (Pleasant Gap, PA). Acetonitrile and nhexane were for HPLC use (J.T. Baker, Deventer, the Netherlands). Total lipids from cheeses were extracted using a published procedure (Mills, 1959). Briefly, $5 \mathrm{~g}$ of cheese, $0.5 \mathrm{~g}$ of potassium oxalate (Fluka Chemie GmbH, Buchs, Switzerland) and $25 \mathrm{~mL}$ of ethyl alcohol (J.T. Baker) were homogenized for 2 min. The homogenized mixtures were poured into a $100-\mathrm{mL}$ centrifuge tube with $10 \mathrm{~mL}$ of diethyl ether and $10 \mathrm{~mL}$ of petroleum ether (J.T. Baker) and were centrifuged at 469 $\times g$ for $7 \mathrm{~min}$ at room temperature. The lower phase was re-extracted 2 more times with $10 \mathrm{~mL}$ of diethyl ether and petroleum ether $(1: 1, \mathrm{vol} / \mathrm{vol})$. The combined organic phases were transferred into $500-\mathrm{mL}$ separatory funnel, where $100 \mathrm{~mL}$ of distilled water and $7.5 \mathrm{~mL}$ of saturated sodium chloride were added. The organic extract was washed 2 more times with $25 \mathrm{~mL}$ of distilled water, any emulsion formed was broken up by the addition of saturated sodium chloride $(2-5 \mathrm{~mL})$, and it was allowed to stand for $30 \mathrm{~min}$. The combined organic layer was dried over anhydrous $\mathrm{Na}_{2} \mathrm{SO}_{4}$ and the organic solvent was removed by rotator evaporator at $38^{\circ} \mathrm{C}$; the total lipids were determined gravimetrically. A portion of total lipids $(50 \mathrm{mg})$ was methylated by $\mathrm{NaOCH}_{3}$ (Sigma-Aldrich Chemie) at $50^{\circ} \mathrm{C}$, was extracted with $n$-hexane, dried over anhydrous $\mathrm{Na}_{2} \mathrm{SO}_{4}$, and analyzed directly by HPLC.

The high-performance liquid chromatograph (Thermo Separation Products, Piscataway, NJ) was equipped with a membrane degasser (LDC Analytical, Riviera Beach, FL), a 10- $\mu \mathrm{L}$ injection loop, and an UV diode array detector (Thermo Separation Products); 3 analytical silver-impregnated columns were fitted in series (ChromSpher 5 Lipids, $4.6 \mathrm{~mm}$ i.d. $\times 250 \mathrm{~mm}$ stainless steel, Varian Medical Equipment Inc.). The mobile phase was $0.5 \%$ diethyl ether anhydrous (J.T. Baker), $0.1 \%$ acetonitrile (J.T. Baker) in $n$-hexane and operated isocratically; the solvent flow was $1.0 \mathrm{~mL} / \mathrm{min}$. The CLA isomers were measured at $234 \mathrm{~nm}$ (Sehat et al., 1998).

\section{Statistical Analysis}

All the variables were tested for normal distribution using the Shapiro-Wilk test (Shapiro and Wilk, 1965). Data were processed by ANOVA, using the GLM procedure of SAS (SAS Institute, 1999). The model used for lipolytic units, FFA, and CLA in rennet paste was

$$
y_{i j k l}=\mu+\alpha_{i}+\beta_{i j}+\varepsilon_{i j k}
$$

where $\mu$ is the overall mean, $\alpha$ is the effect of type of rennet ( $i=1$ to 3 ), $\beta$ is the individual cheese variation within type of rennet, and $\varepsilon$ is the error.

The model used for FFA and CLA in cheese was

$$
y_{i j k l}=\mu+\alpha_{i}+\beta_{i j}+\gamma_{k}+\varepsilon_{i j k l}
$$

where $\mu$ is the overall mean, $\alpha$ is the effect of type of rennet ( $i=1$ to 3 ), $\beta$ is the cheese variation within type 


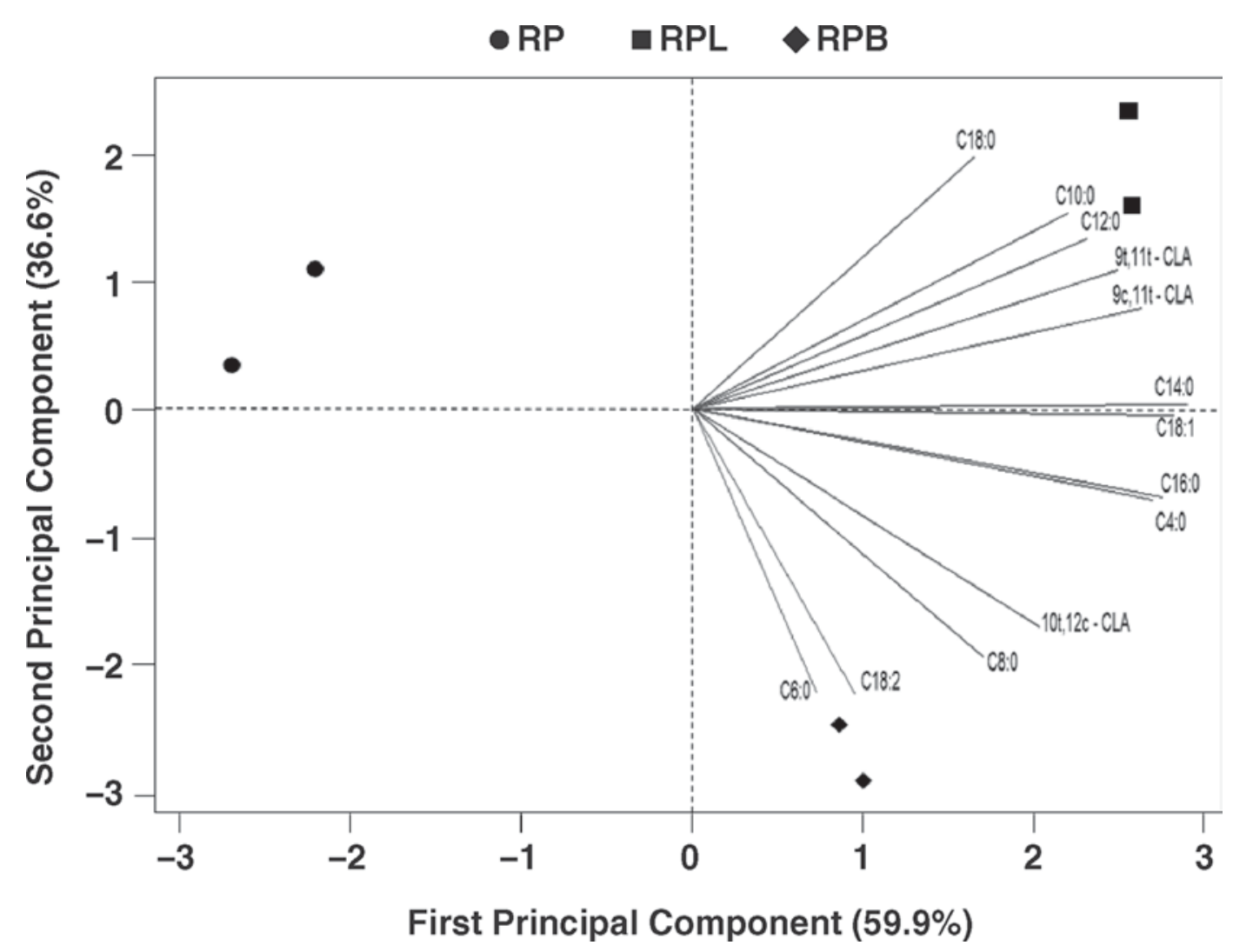

Figure 1. Principal component analysis of the FFA and CLA isomers in the sheep milk cream incubated with different rennet paste: $\bullet$ RP, traditional lamb rennet paste, $\mathbf{R P L}$, lamb rennet paste containing Lb. acidophilus; - RPB, lamb rennet paste containing $B$. lactis and $B$. longum. $\mathrm{c}=$ cis; $\mathrm{t}=$ trans.

of rennet, $\gamma$ is the effect of ripening time $(k=1$ to 5$)$, and $\varepsilon$ is the error. A $P$-value of $P<0.05$ was considered to indicate significant differences. The effect of ripening time, which turned out to be significant for FFA and CLA in all cheeses, was not shown in the table. Values recorded in sheep milk cream without rennet paste were used as covariates for FFA and CLA content measured in sheep milk cream incubated with experimental rennet paste. Principal component analyses (PCA) were performed by SCAN for Windows (Minitab Inc., State College, PA), to obtain a visual representation of free fatty acids and CLA isomer distribution in sheep milk cream and in cheese samples.

\section{RESULTS AND DISCUSSION}

In a previous paper (Santillo and Albenzio, 2008), the influence of lamb rennet paste containing $L b$. acidophilus and a mix of B. longum and B. lactis on chemical and microbiological features, proteolysis, and rheological properties of Pecorino cheese was studied. Moreover, in the same paper, microbial counts were performed at different time of cheese ripening, display- ing constant counts of 8 and $9 \log _{10} \mathrm{cfu} / \mathrm{g}$, respectively for L. acidophilus and Bifidobacterium spp. mix. The authors highlighted that cheese obtained using rennet with bifidobacteria showed greater proteolysis and lower hardness; although differences in proteolytic patterns were found, this did not account for contribution in smell and taste scores.

Lipase activity on sheep milk cream substrate measured the contribution of both endogenous and microbial lipase. Total lipolytic activity detected in the sheep milk cream substrate, after incubation at $37^{\circ} \mathrm{C}$ for 24 $\mathrm{h}$, was the lowest $(2,906 \pm 356.6 \mathrm{LU} / \mathrm{g})$ in rennet without probiotics (RP) and the greatest in rennet paste containing Lb. acidophilus (RPL; 5,957 $\pm 374.5 \mathrm{LU} / \mathrm{g}$ ) and a mix of B. longum and B. lactis (RPB; 5,654 \pm $367.4 \mathrm{LU} / \mathrm{g}$ ). These data confirmed the ability of $L b$. acidophilus to increase lipolytic activity of rennet paste according to Santillo et al. (2007) and highlighted that also B. longum and B. lactis are able to contribute to lipase activity in rennet paste.

The FFA and CLA profiles of sheep milk cream substrate incubated with experimental rennet paste with and without probiotics addition are reported in Table 
Table 3. Free fatty acid ( $\mu$ mol per $g$ of cheese) profile of Pecorino cheese manufactured using different rennet pastes ${ }^{1}$ during ripening

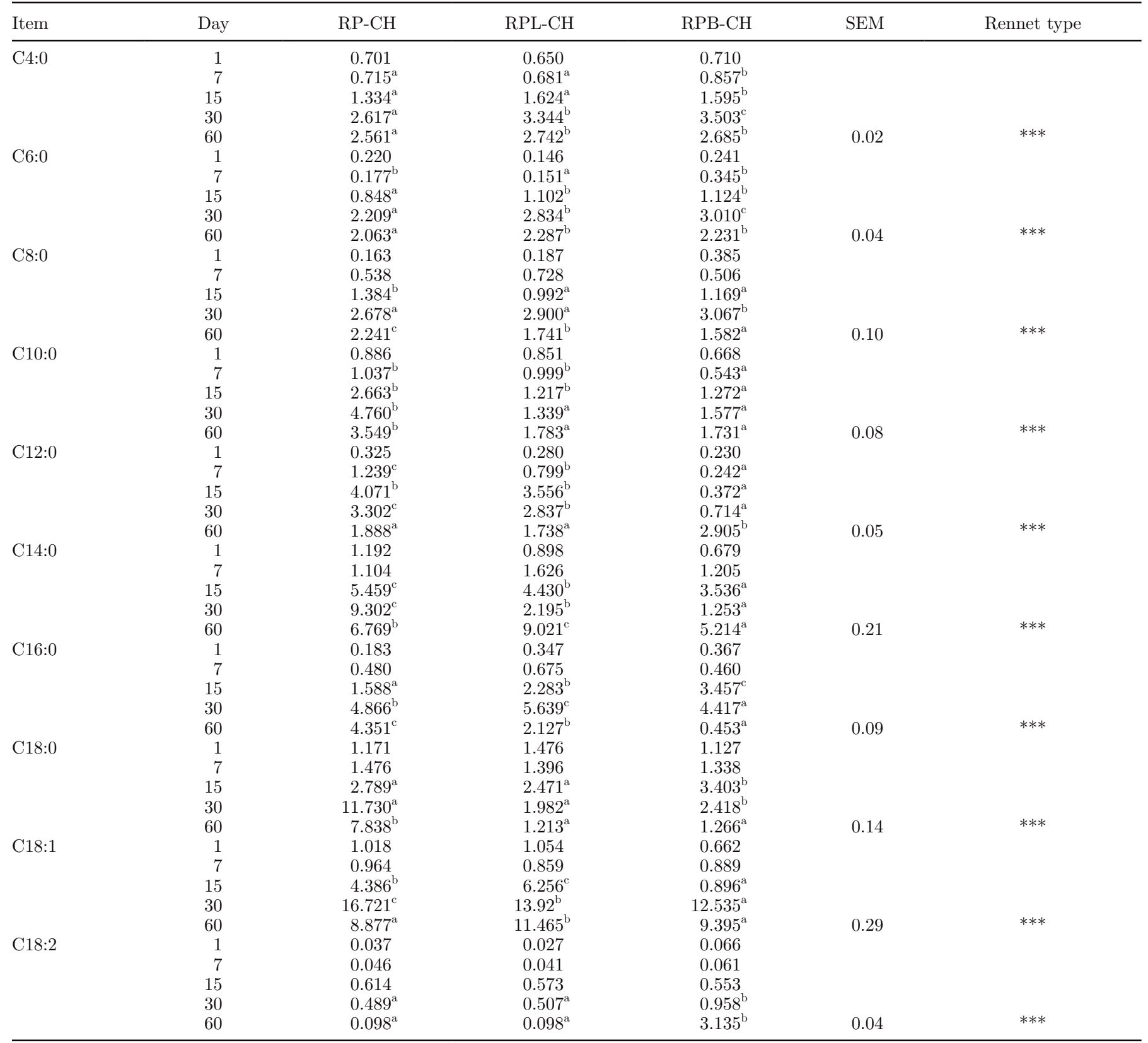

${ }^{\mathrm{a}-\mathrm{c}}$ Means in rows with different superscripts differ for each item $(P<0.05)$.

${ }^{1} \mathrm{RP}-\mathrm{CH}=$ cheese manufactured using traditional lamb rennet paste; RPL-CH $=$ cheese manufactured using lamb rennet paste containing Lactobacillus acidophilus; RPB-CH = cheese manufactured using lamb rennet paste containing Bifidobacterium lactis and Bifidobacterium longum.

*** $P<0.001$

2. Total FFA content was lower in RP $(4.66 \mu$ mol per $\mathrm{g}$ of milk cream) than in RPL $(6.72 \mu \mathrm{mol}$ per $\mathrm{g}$ of milk cream) and in RPB $(5.21 \mu$ mol per g of milk cream) according to lipase activity of rennet paste. Bustamante et al. (2000) and Addis et al. (2005) found that lipase contained in rennet paste is responsible for liberating mainly short-chain fatty acids from milk fat; in par- ticular, rennet paste obtained from suckling lambs slaughtered just after suckling are able to produce a large amount of butyric acid because of the presence of pregastric esterase. In this study, butyric acid released by rennet paste containing probiotics was $50 \%$ greater than control rennet. Accordingly, El Soda et al. (1995) reported that butyric acid is formed principally by 
Table 4. Total conjugated linoleic acid (CLA; $\mu$ mol per g of cheese) profile of Pecorino cheese manufactured using different rennet paste ${ }^{1}$ during ripening

\begin{tabular}{|c|c|c|c|c|c|c|}
\hline Item & Day & $\mathrm{RP}-\mathrm{CH}$ & $\mathrm{RPL}-\mathrm{CH}$ & $\mathrm{RPB}-\mathrm{CH}$ & SEM & Rennet type \\
\hline \multirow{3}{*}{ 9-trans, 11-trans CLA } & 7 & $0.51^{\mathrm{a}}$ & $0.681^{\mathrm{b}}$ & $0.530^{\mathrm{a}}$ & & \\
\hline & 15 & $0.569^{\mathrm{a}}$ & $0.497^{\mathrm{a}}$ & $0.630^{\mathrm{b}}$ & & \\
\hline & 60 & $0.548^{\mathrm{b}}$ & $0.716^{\mathrm{a}}$ & $0.364^{\mathrm{a}}$ & 0.03 & $*$ \\
\hline \multirow[t]{2}{*}{ 10-trans, 12-cis CLA } & 1 & 0.044 & 0.038 & 0.091 & & \\
\hline & 7 & $0.065^{\mathrm{a}}$ & $0.076^{\mathrm{a}}$ & $0.126^{\mathrm{b}}$ & & \\
\hline \multirow[t]{5}{*}{ 9-cis, 11-trans CLA } & 1 & 9.675 & $8.809^{\mathrm{a}}$ & $10.058^{\mathrm{b}}$ & & \\
\hline & 7 & 12.378 & 11.979 & 13.060 & & \\
\hline & 15 & $13.011^{\mathrm{a}}$ & $12.255^{\mathrm{a}}$ & $14.671^{\mathrm{b}}$ & & \\
\hline & 30 & 12.858 & $11.770^{\mathrm{a}}$ & $13.318^{\mathrm{b}}$ & & \\
\hline & 60 & $13.132^{\mathrm{b}}$ & $14.606^{\mathrm{c}}$ & $7.882^{\mathrm{a}}$ & 0.39 & * \\
\hline
\end{tabular}

${ }^{\mathrm{a}-\mathrm{c}}$ Means in rows with different superscripts differ for each item $(P<0.05)$.

${ }^{1} \mathrm{RP}-\mathrm{CH}=$ cheese manufactured using traditional lamb rennet paste; RPL-CH $=$ cheese manufactured using lamb rennet paste containing Lactobacillus acidophilus; RPB-CH = cheese manufactured using lamb rennet paste containing Bifidobacterium lactis and Bifidobacterium longum.

${ }^{*} P<0.05 ;{ }^{* *} P<0.01$.

lipolytic activity of lactic acid bacteria. Lamb rennet containing $L b$. acidophilus showed the greatest levels of C10:0, C12:0, and C18:0, whereas RPB had higher concentration of C6:0, C8:0, and C18:2, the level of the latter being $80 \%$ greater than that found in RP and RPL.

It is well known that dairy products are the major dietary source of CLA, of which 9-cis 11-trans CLA is the main isomer, produced by rumen microorganisms and by $\Delta^{9}$-desaturase in the mammary gland ( $\mathrm{Oh}$ et al., 2003; Sieber et al., 2004). Coakley et al. (2003) suggested that the 9-trans 11-trans CLA isomer is a product of further conversion of the main isomer. Probiotics added to rennet paste were found to influence the CLA content in sheep milk cream substrate; rennet paste containing $L b$. acidophilus was characterized by the greatest contents of 9-cis 11-trans and 9-trans 11-trans CLA in accordance with Alonso et al. (2003), who found that some strains of $L b$. acidophilus are able to produce CLA from free linoleic acid. Rennet containing a mix of B. lactis and B. longum displayed the greatest levels of 10-trans, 12-cis CLA according to previous findings of Coakley et al. (2003), who found that B. lactis had a good ability to produce this isomer from linoleic acid. A PCA biplot relevant to FFA and CLA composition of sheep milk cream incubated with different rennet paste, shown in Figure 1, confirmed data in Table 2. The PCA highlighted that sheep milk creams incubated with rennet paste containing probiotics showed large positive loadings with the first principal component denoting greater FFA and CLA contents than those incubated with traditional rennet.
Moreover, the type of probiotic strain added to rennet can influence the amount and the quality of lipolytic pattern, in particular, as concerns the CLA and C18:2 contents. On the contrary, butyric acid and palmitic acid, equidistant from the points representing RPL and RPB samples, were produced in the same amount by $L b$. acidophilus and a mix of B. lactis and B. longum.

The profiles of individual FFA composition of ovine cheese during ripening are reported in Table 3. As expected, at $1 \mathrm{~d}$ of ripening no differences were found among cheeses; during the first phase of ripening, slight differences were noticed for short chain fatty acid (C4:0, C6:0, C8:0, and C10:0) and for C12:0. Major increases of FFA occurred at $30 \mathrm{~d}$, with the largest values being reported for $\mathrm{C} 16: 0, \mathrm{C} 18: 0$, and $\mathrm{C} 18: 1$. At $60 \mathrm{~d}$ of ripening, all cheeses showed a reduction in the amount of FFA; in particular, total FFA underwent a decrease of more than $30 \%$ from 30 to $60 \mathrm{~d}$ in RP-CH, displaying a value of $40.23 \mu \mathrm{mol} / \mathrm{g}$ of cheese at the end of ripening. The same parameter decreased by $10 \%$ in RPL-CH and RPB-CH samples $(34.21 \mu \mathrm{mol}$ per $\mathrm{g}$ of cheese and 30.59 $\mu$ mol per $\mathrm{g}$ of cheese at $60 \mathrm{~d}$, respectively). The decrease in total FFA found in all the experimental cheeses from 30 to $60 \mathrm{~d}$ of ripening could be an outcome of the catabolism of FFA, which occurred at a faster rate than FFA production. Free fatty acids, in fact, are precursor molecules for a series of catabolic reactions leading to the production of flavor and aroma compounds such as methyl ketones, esters, secondary alcohols, lactones, and aldehydes (Collins et al., 2003). Figure 2 shows the PCA biplot for the CLA and FFA composition of the cheese samples; the FFA content was the main factor ex- 


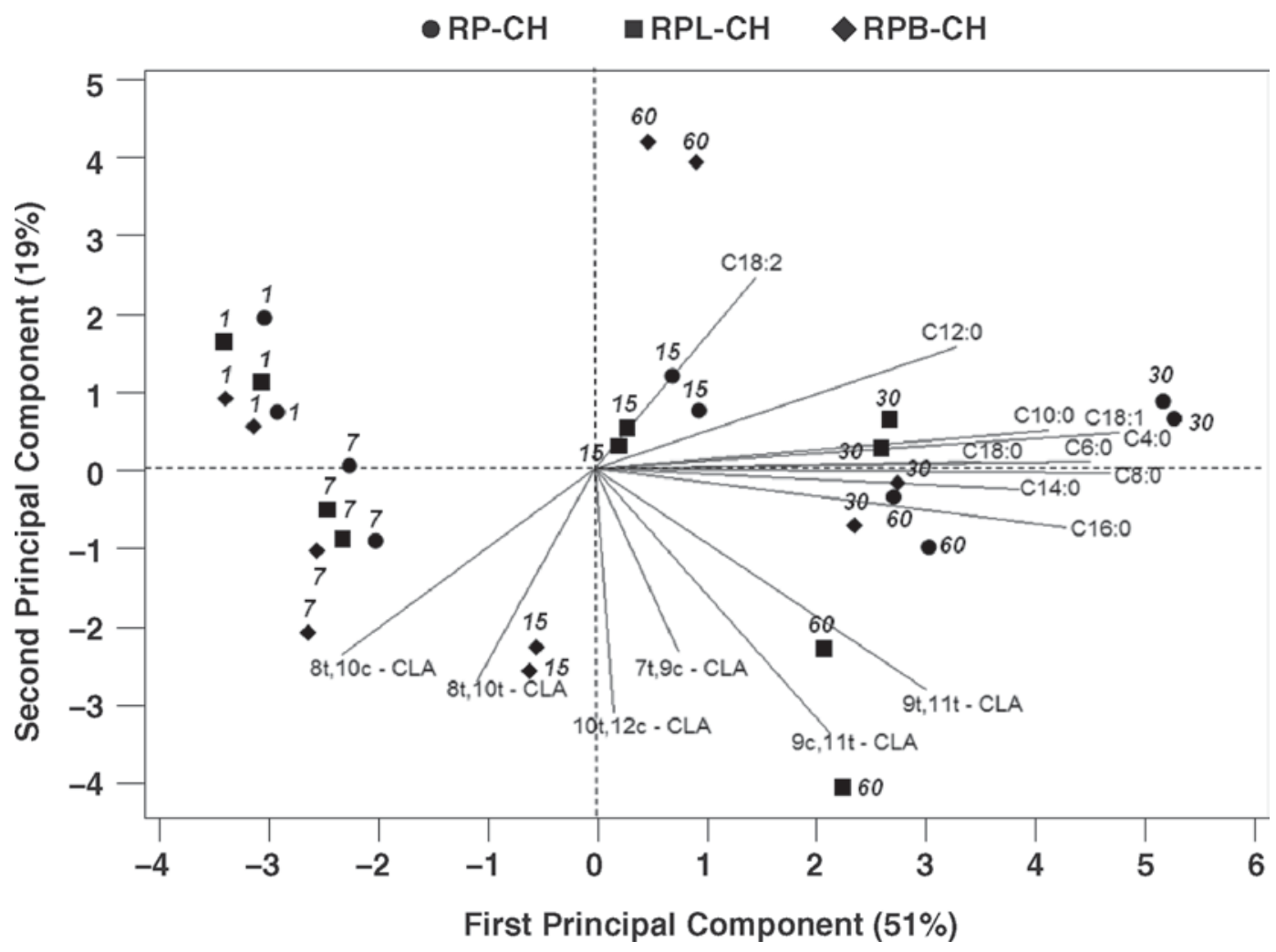

Figure 2. Principal component analysis of the FFA and CLA isomers of Pecorino cheese manufactured with different rennet paste: $\bullet$ RP-CH, cheese manufactured using traditional lamb rennet paste; RPL-CH, cheese manufactured using lamb rennet paste containing Lb. acidophilus; - RPB-CH, cheese manufactured using lamb rennet paste containing B. lactis and B. longum. $\mathrm{c}=$ cis; $\mathrm{t}=$ trans.

plained by the first principal component while the CLA content was the dominating factor along the second principal component. Total CLA profiles of cheese are reported in Table 4. At 15 d of ripening RPB-CH was characterized by higher concentration of 8-trans, 10cis CLA, 8-trans, 10-trans CLA, 10-trans, 12-cis CLA, 7-trans, 9-cis CLA, as demonstrated by the loading plot of the variables, denoting the ability of $B$. lactis and $B$. longum to produce CLA in the cheese matrix. The score plot showed how the points that represent RPB-CH at $60 \mathrm{~d}$ of ripening lie in a zone where C18:2 concentration was higher if compared with those of the other cheeses, in accordance with the result found in sheep milk cream substrate. The great importance of linoleic acid in the cheese has to be related to the location of this fatty acid on the milk triacylglycerol mainly at the $s n-1$ and $s n-3$ position, which are the specific hydrolysis sites for the lipolytic enzymes (Balcao and Malcata, 1998). The reason why bacteria would convert linoleic acid to CLA is unclear; Jiang et al. (1998) proposed that conversion of linoleic acid into CLA may be a detoxification mechanism to avoid the growth-inhibitory effect of fatty acid. The opposite position of C18:2 and CLA with respect to the second principal component loading in the PCA biplot confirms the findings of Van Nieuwenhove et al. (2007) reporting that the strain of bifidobacteria tested showed greater percentage of conversion in correspondence with low linoleic acid concentration. The highest concentration of C18:2 detected in both sheep milk cream and cheese has to be considered a limiting factor to CLA formation by B. lactis and B. longum. Cheese containing $L b$. acidophilus reached a maximum value of FFA after $30 \mathrm{~d}$, and at the end of ripening was characterized by the greatest levels of 9-cis 11-trans CLA and 9-trans 11-trans CLA. This result confirmed the CLA production capabilities of Lb. acidophilus in cheese previously reported by Santillo et al. (2007); however, values from the present survey were found to be greater than those reported in other ovine cheeses (Zlatanos et al., 2002). The quantitatively predominant CLA isomer in milk is 9-cis 11-trans CLA, which has been implicated as the most important isomer in terms of biological activity (Luna et al., 2005) for reduction of cancer risk, low-density lipoprotein concentration, increased body protein, and reduced whole-body fat (Sieber et al., 2004). 


\section{CONCLUSIONS}

Rennet paste containing viable cells of $L b$. acidophilus and of B. lactis and B. longum was able to influence the amount of FFA and CLA in Pecorino cheese during ripening. Lactobacillus acidophilus contained in lamb rennet paste showed a high CLA-producing ability so that the greatest levels of 9-cis 11-trans CLA and 9-trans 11-trans CLA were found both in sheep milk cream and in the cheese. Bifidobacteria displayed CLA-producing ability too, although lower than that of lactic acid bacteria, and the corresponding cheese was characterized by the greatest levels of linoleic acid. The different production of CLA and linoleic acid by probiotics added to lamb rennet paste could be a possible way to enhance health properties of ovine cheese. A novel lamb rennet paste may offer opportunities in the development of traditional Pecorino cheese with functional properties.

\section{ACKNOWLEDGMENTS}

The authors thank Monica Dentico of the Department of Agro-Environmental Science, Chemistry and Plant Protection (Di.S.A.C.D., University of Foggia, Italy) for expert technical assistance.

\section{REFERENCES}

Addis, M., A. Pirisi, R. Di Salvo, F. Podda, and G. Piredda. 2005. The influence of the enzymatic composition of lamb rennet paste on some properties of experimentally produced PDO Fiore Sardo cheese. Int. Dairy J. 15:1271-1278.

Alonso, L., E. P. Cuesta, and S. E. Gilliland. 2003. Production of free conjugated linoleic acid by Lactobacillus acidophilus and Lactobacillus casei of human intestinal origin. J. Dairy Sci. 86:1941-1946.

Balcao, V. M., and F. X. Malcata. 1998. Lipase catalysed modification of milk fat. Biotechnol. Adv. 16:309-341.

Bustamante, M., F. Chávarri, A. Santisteban, G. Ceballos, I. Hernández, M. J. Miguélez, I. Aramburu, L. J. R. Barrón, M. Virto, and M. De Renobales. 2000. Coagulating and lipolytic activities of artisanal lamb rennet pastes. J. Dairy Res. 67:393-402.

Cabiddu, A., M. Addis, G. Pinna, S. Spada, M. Fiori, M. Sitzia, A. Pirisi, G. Piredda, and G. Molle. 2006. The inclusion of a daisy plant (Chrysanthemum coronarium) in dairy sheep diet. 1: Effect on milk and cheese fatty acid composition with particular reference to C18:2 cis-9, trans-11. Livest. Sci. 101:57-77.

Coakley, M., R. P. Ross, M. Nordgren, G. Fitzgerald, R. Devery, and C. Stanton. 2003. Conjugated linoleic acid biosynthesis by humanderived Bifidobacterium species. J. Appl. Microbiol. 94:138-145.

Collins, Y. F., P. L. H. MacSweeney, and M. G. Wilkinson. 2003 Lipolysis and free fatty acid catabolism in cheese: A review of current knowledge. Int. Dairy J. 13:841-866.

de Jong, C., and H. T. Badings. 1990. Determination of free fatty acids in milk and cheese. Procedures for extraction, clean up, and capillary gas chromatographic analysis. J. High Resolut. Chrom. 13:94-98.

Deeth, H. C., and C. H. Fitz-Gerald. 1995. Lipolytic enzymes and hydrolytic rancidity in milk and milk products. Page 247 in
Advanced Dairy Chemistry. Vol. 2. Lipids. P. F. Fox, ed. Chapman \& Hall, London, UK.

El Soda, M., N. Farkye, J. C. Vuillemard, R. E. Simard, N. F. Olson, W. El Kholy, E. Dako, E. Medrano, M. Gaber, and L. Lim. 1995. Autolysis of lactic acid bacteria: Impact on flavor development in cheese. Pages 2205-2223 in Food Flavors: Generation, Analysis and Process Influence. G. Charalambous, ed. Elsevier Science B.V., Amsterdam, the Netherlands.

Fox, P. F., and J. M. Wallace. 1997. Formation of flavor compounds in cheese. Adv. Appl. Microbiol. 45:17-85.

Ha, K. J., and R. C. Lindsay. 1990. Method for the quantitative analysis of volatile free and total branched-chain fatty acids in cheese and milk fat. J. Dairy Sci. 73:1988-1999.

Jiang, J., L. Björck, and R. Fondén. 1998. Production of conjugated linoleic acid by dairy starter cultures. J. Appl. Microbiol. 85:95102.

Luna, P., J. Fontecha, M. Juárez, and M. A. de la Fuente. 2005. Changes in the milk and cheese fat composition of ewes fed commercial supplements containing linseed with special reference to the CLA content and isomer composition. Lipids 40:445-454.

McSweeney, P. L. H., and M. J. Sousa. 2000. Biochemical pathways for the productions of flavor compounds in cheese during ripening: A review. Lait 80:293-324.

Mills, P. A. 1959. Detection and semiquantitative estimation of chlorinated organic pesticide residues in foods by paper chromatography. J. AOAC Int. 42:734-740.

Nelson, J. H., R. G. Jensen, and R. E. Pitas. 1977. Pregastric esterase and other oral lipase-A review. J. Dairy Sci. 60:327-362.

Oh, D. K., G. H. Hong, Y. Lee, S. Min, H. S. Sin, and S. K. Cho. 2003. Production of conjugated linoleic acid by isolated Bifidobacterium strains. World J. Microbiol. Biotechnol. 19:907-912.

Pinho, O., I. M. P. L. V. O. Ferreira, and M. A. Ferreira. 2003. Quantification of short-chain free fatty acids in "Terrincho" ewe cheese: Intravarietal comparison. J. Dairy Sci. 86:3102-3109.

Richardson, G. H., J. H. Nelson, and M. G. Farnham. 1971. Gastric lipase characterization and utilization in cheese manufacture. J. Dairy Sci. 54:643-647.

Santillo, A., and M. Albenzio. 2008. Influence of lamb rennet paste containing probiotic on proteolysis and rheological properties of Pecorino cheese. J. Dairy Sci. 91:1733-1742.

Santillo, A., M. Quinto, M. Dentico, A. Muscio, A. Sevi, and M. Albenzio. 2007. Rennet paste from lambs fed a milk substitute supplemented with Lactobacillus acidophilus: Effects on lipolysis in ovine cheese. J. Dairy Sci. 90:3134-3142.

SAS Institute. 1999. SAS User's Guide: Statistics, Version 8.1 ed. SAS Inst. Inc., Cary, NC.

Sehat, N., J. K. G. Kramer, M. M. Mossoba, M. P. Yurawecz, J. A. G. Roach, K. Eulitz, K. M. Morehouse, and Y. Ku. 1998. Identification of conjugated linoleic acid isomers in cheese by gas chromatography, silver ion high performance liquid chromatography and mass spectral reconstructed ion profiles. Comparison of chromatographic elution sequences. Lipids 33:963-971.

Shapiro, S. S., and M. Wilk. 1965. An analysis of variance test for normality. Biometrika. 52:591-601.

Sieber, R., M. Collomb, A. Aeschlimann, P. Jelen, and H. Eyer. 2004. Impact of microbial cultures on conjugated linoleic acid in dairy products-A review. Int. Dairy J. 14:1-15.

Van Nieuwenhove, C. P., R. Oliszewski, S. N. González, and A. B. Pérez Chaia. 2007. Conjucated linoleic acid conversion by dairy bacteria cultured in MRS broth and buffalo milk. Lett. Appl. Microbiol. 44:467-474.

Zhang, R., A. F. Mustafa, and X. Zhao. 2006. Effects of flaxseed supplementation to lactating ewes on milk composition, cheese yield, and fatty acid composition of milk and cheese. Small Rumin. Res. 63:233-241.

Zlatanos, S., K. Laskaridis, C. Feist, and A. Sagredos. 2002. CLA content and fatty acid composition of Greek Feta and hard cheeses. Food Chem. 78:471-477. 